HELLYER Mark,

Postgraduate student of Department of World Economics

Kyiv National University of Trade and Economics,

Director of CTA Economic \& Export Analysts (United Kingdom),

19, Kyoto str., Kyiv, 02156, Ukraine

E-mail:markhellyer@me.com

ORCID: https://orcid.org/0000-0001-5665-4052

\title{
UKRAINE'S TRADE UNDER THE DCFTA: A GRAVITY MODEL
}

The article analyses the trade performance of Ukraine under the Deep and Comprehensive Free Trade Area (DCFTA). The practical results of the application of the DCFTA provisions on Ukraine's exports to the EU are presented and compares the results of a gravity model with actual trade to determine whether Ukraine's exports to the EU under the DCFTA have performed as expected. The findings follow with both traditional economic theory and ex ante models that expected a significant increase in exports overall and above normal trade growth and yet the reality has shown the contrary suggesting such ex ante modelling is not relevant or accurate for policy makers negotiating such agreements.

Keywords: trade liberalization, the Deep and Comprehensive Free Trade Area, economic growth, tariffs, exports, preferential trade agreements, gravity model.

Хеллаер М. Торговля Украины в рамках УВЗСТ: гравитационная модель. В статье анализируются торговые показатели Украины в условиях углубленной и всеобъемлющей зоны свободной торговли (УВЗСТ). Представлены практические результаты применения положений УВЗСТ к экспорту Украины в ЕС. Проведено сравнение результатов гравитаиионной модели с фактической торговлей, чтобы определить был ли экспорт Украины в ЕС в рамках УВЗСТ осуществлен так, как ожидалось. Полученные результаты основаны как на традиционной экономической теории, так и на моделях ех ante, согласно которым ожидалось значительное увеличение экспорта в целом и выше нормального торгового роста. Однако реальность показала обратное, а, следовательно, можно предположить, что моделирование ех ante не актуально или не достаточно точно для политиков, ведущих переговоры по подобным соглашениям.

Ключевые слова: либерализация торговли, глубокая и всеобъемлющая зона свободной торговли, экономический рост, тарифы, экспорт, преференциальные торговые соглашения, гравитационная модель.

Background. Negotiation of an Association Agreement (AA) between EU and Ukraine were concluded and signed in Brussels on 21 March 2014 with provisions for the creation of a Deep and Comprehensive Free Trade Area (DCFTA) applied from $1^{\text {st }}$ January 2015 . Broadly speaking, the AA opens up the EU market by offering reduced tariff access and in parallel Ukraine will adopt a vast range of EU legislation that will align with the rules in the EU over the next 10 years and make it easier for business to export.

(c) Hellyer M., 2019

20 
Analysis of recent research and publications. The expectations of the EU, Government and citizens of Ukraine was that this would bring Ukraine closer to the EU and lead to increased exports from Ukraine to the EU market. Most studies predicted a positive impact on Ukraine's trade[1-7] and others developed computable general equilibrium (CGE) models [8-11] that predicted ex ante increases in exports of Ukraine of between 6.3 and $15 \%$ in the short term (measured as 1 year impact in most cases) over and above any expected export growth (table 1).

Table 1

\section{Predicted Impact of DCFTA on Ukraine's Exports to EU}

\begin{tabular}{|c|c|c|c|c|}
\hline Author(s) & Date & Method of estimation & $\begin{array}{c}\text { Aggregate Impact } \\
\text { (Ukraine's } \\
\text { exports to EU), \% }\end{array}$ & $\begin{array}{c}\text { Timeframe } \\
\text { for impact }\end{array}$ \\
\hline $\begin{array}{c}\text { K. Berden, } \\
\text { F. Smakman, } \\
\text { P. Wymenga [8] }\end{array}$ & 2007 & $\begin{array}{c}\text { Computable General } \\
\text { equilibrium (CGE) model }\end{array}$ & +6.4 & 1 year \\
\hline V. Sidenko [9] & 2007 & $\begin{array}{c}\text { Computable General } \\
\text { equilibrium (CGE) model }\end{array}$ & +15 & Short Term \\
\hline $\begin{array}{c}\text { V. Movchan, } \\
\text { R. Giucci [10] }\end{array}$ & 2011 & $\begin{array}{c}\text { Computable General } \\
\text { equilibrium (CGE) model }\end{array}$ & +6.3 & Immediate \\
\hline $\begin{array}{c}\text { Institute for Economic } \\
\text { Research and Policy } \\
\text { Consulting [11] }\end{array}$ & 2014 & $\begin{array}{c}\text { Computable General } \\
\text { equilibrium (CGE) model }\end{array}$ & +9.9 & 1 year \\
\hline $\begin{array}{c}\text { A. Kravchuk, } \\
\text { Z. Popovych [12] }\end{array}$ & 2016 & $\begin{array}{c}\text { GTAP Computable General } \\
\text { equilibrium (CGE) model }\end{array}$ & +1 & Immediate \\
\hline
\end{tabular}

Source: composed by the author on the results of various sources analysis.

However, exports to the EU from Ukraine have not performed as expected at an aggregate level. Ukraine's exports to the EU initially declined after application of DCFTA trade provision (autonomous trade preferences applied in early 2014) with $-6.7 \%$ growth and in 2015 and increased by $3.4 \%$ in 2016 (calculated by the author from Eurostat data). Whilst growth in exports to the EU was an impressive $24.7 \%$ in 2017, Ukraine's export growth to EU in 2018 was a more modest $8.0 \%$.

To compare actual short term performance with the predicted short term (one year impact), a smoothed data approach is used of a 3 year moving average of trade so that the immediate trade impact of the DCFTA is average growth between 2015-2017 for the first year after the application of DCFTA trade provisions and 2016-2018 for the second year. Average growth in Ukraine's exports to the EU post DCFTA was only $7.6 \%$ (2015-2017) compared with $7.6 \%$ (2011-2013) prior to the application of the DCFTA showing immediately no apparent effect. Even for the second year (20162018), average export growth to the EU was $12.4 \%$, so compared with pre DCFTA growth, the increase in exports post DCFTA is only $4.8 \%$. These are below any of the predictions of ex ante CGE models.

Indeed, immediate short term average exports post DCFTA implementation (2015-2017) were $€ 13.8$ billion compared with $€ 14.1$ billion pre 
DCFTA (2011-2013). This means that the short term (3-year average) impact of the DCFTA has been a decline of $2.3 \%$ in exports compared with the $6.3-15.0 \%$ expected by models.

Therefore, the aim of this paper is to examine whether the predictions and the expectations are reasonable and thus indicated that other factors have played a role that policy makers could investigate to "unlock" the potential of the AA/DCFTA. If the ex-ante predictions are accurate, then it is important for policy makers in Ukraine to analyse which other factors are constraining the potential of the AA/DCFTA and if addressed, could unlock trade to the EU. Whereas, if these CGE models are not good predictors of the effects of Ukraine's trade under the DCFTA, and actual export performance is what could reasonably be expected, then other policies to promote and develop exports should be pursued.

Materials and methods. The literature on Ukraine's export performance to the EU under the DCFTA has preferred the use of CGE modelling. However, gravity models are popular empirical trade devices that have been used widely for analysing the impact of different trade policy issues on bilateral trade flows between different geographical entities whereas CGE models are generally used to quantify the impact of a change in trade policy on the countries' welfare and the distribution of income across countries [13].

Therefore, the absence of any gravity modelling on Ukraine's exports with the EU under the DCFTA could mean that the CGE model approach created higher expectations than could reasonably of mean expected given they aim principally at welfare rather than trade gains. Gravity models have been shown to be amongst the most empirically robust relationships in economics [14; 15] with Disdier and Head [16] meta-analysis of 1.467 estimations showing stable and accurate results. Leamer and Levinsohn [17] also conclude that "Some of the clearest and most robust findings in empirical economics."

Therefore, in order to confirm the expected impact of the AA/DCFTA, a gravity model (based on pooled panel data) of countries associated with or recently acceded to the EU was developed to compare the expected results of these ex-ante models.

The model is based on the idea that trade between two countries, like the gravitational force between two objects, is a function of the countries' "mass" (in this case, population size and GDP as well as the distance between them). Tinbergen [18] first presented the gravity model in 1962 specifying that the trade between two countries is relative to their size in GDP and distance between them, as follows:

\section{Equation 1: Traditional Gravity Model Specification}

$$
T_{A, B}=\frac{\left(G D P_{A}\right)^{\alpha} \cdot\left(G D P_{B}\right)^{\beta}}{D I S T_{A B}{ }^{\gamma}}
$$

with coefficients $\alpha, \beta, \zeta \approx 1$. 
Despite the high level of success in gravity models explaining trade between two countries, these models were used in a "theoretical" vacuum until Krugman's [19] seminal work on theory of gravity models. He theorised with costs to firms and market demand to prove from an economic perspective to derive the gravity formula. In this theory, the GDP is used as a proxy to the traditional Ricardian comparative advantage in relation to relative production and market demands. Distance is then the proxy for trade cost between the two countries (assuming transport being the main cost) and therefore affects the level of trade; that is in some way this addresses the "frictionless trade" assumption of comparative advantage.

Linnemann [20] included population as an additional measure of country size, in what was one of the first "augmented gravity models" and it is also common to instead specify the augmented model using per capita income, which captures the same effects. Other economists have then specified other "trade costs" as the denominator to assess the impact of specific policies including average tariff rates, SPS restrictions etc. [21]. A review of the range of gravity models including dependent variables and statistical method employed is provided by Kepaptsoglou et al (2010) [22] for 53 studies using gravity models and the most relevant references relating to trade agreement analysis is presented in table 2.

Fixed effect gravity models use dummies to assess trade impact of specific trade policies on trade, most commonly the impact of FTAs [23]. These fixed effect models also have the benefit of overcoming heteroskedasticity inherent in gravity models whereby the structural form is affected by policies such as signing an agreement or change in exchange rate regime.

In specifying and estimating the model, recommendations from Baldwin and Taglione [24], where used to ensure better results:

1. Unobserved variables are correlated with error term (autocorrelation) so pooled panel data should be used to avoid this.

2. Gravity is an expenditure equation explaining the value of spending by one nation on the goods produced by another nation (EU) so average trade flows include spending in the other nation so in this model, only imports from Ukraine are used (Ukrainian exports).

3. Gravity is an expenditure function allocating nominal GDP into nominal imports so variables are not deflated for either trade flows or GDP.

Therefore, based on the plethora of research and evidence available, a fixed effect gravity model of EU imports from partners was developed to assess the impact of the AA/DCFTA on Ukraine's trade using the following specification:

Equation 2: Gravity Equation with Accession Dummy

$$
X_{U k r, E U}=\frac{\left(G D P_{U k r}\right)^{\alpha} \cdot\left(G D P_{E U}\right)^{\beta} \cdot D^{\delta}}{D I S T_{U k r E U}{ }^{\gamma}}
$$

$X_{U k r, E U}$ - exports from Ukraine to the EU (measured by EU imports from Ukraine);

$G D P_{U k r}$ - nominal GDP of Ukraine;

$G D P_{E U}$ - nominal GDP of EU;

Dist $_{U k r E U}$ - distance between Kiev and Berlin;

$D$ - Dummy for Signature of Association Agreement. 


\begin{tabular}{|c|c|c|c|c|c|c|c|c|c|}
\hline \multirow{7}{*}{ 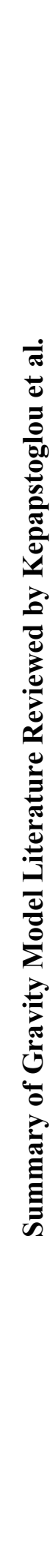 } & 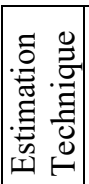 & $\tilde{0}$ & $\sqrt{0}$ & 永 & $\tilde{0}$ & $\tilde{0}$ & 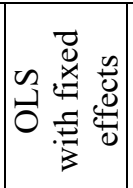 & 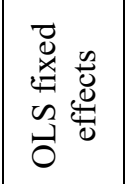 & $\stackrel{n}{0}$ \\
\hline & 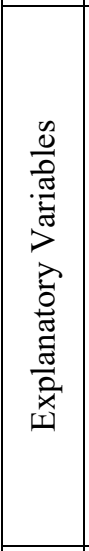 & 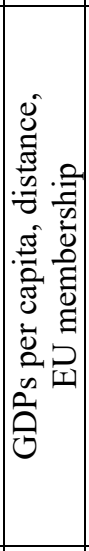 & 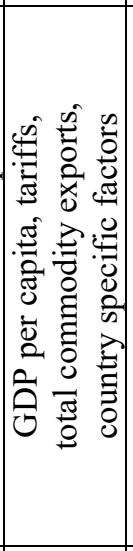 & 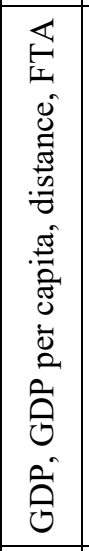 & 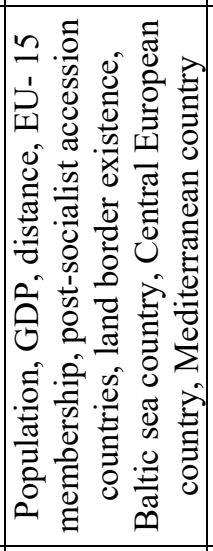 & 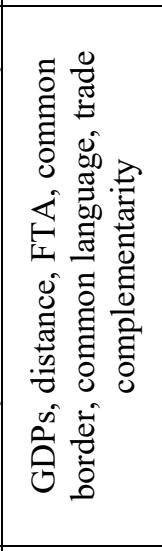 & 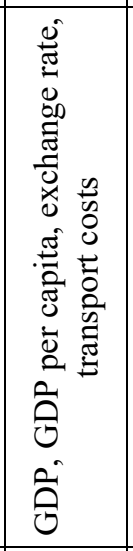 & 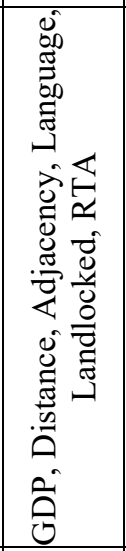 & 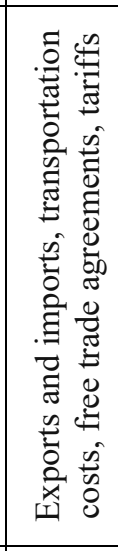 \\
\hline & 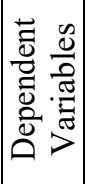 & 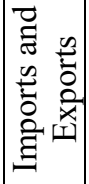 & 咅 & 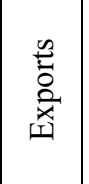 & 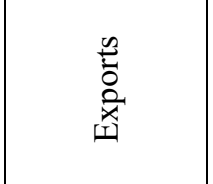 & 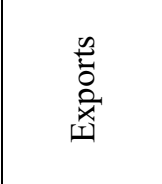 & 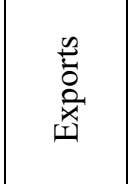 & 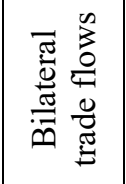 & 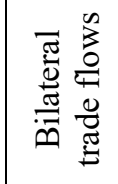 \\
\hline & $\begin{array}{l}\vec{\Phi} \\
\tilde{\Xi} \\
\tilde{\Xi} \\
\tilde{\Xi}\end{array}$ & 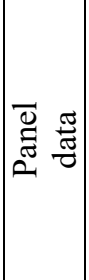 & $\begin{array}{l}\bar{\Xi} \\
\stackrel{\pi}{\pi} \\
\tilde{\sigma}\end{array}$ & 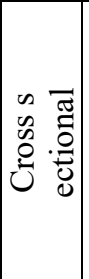 & 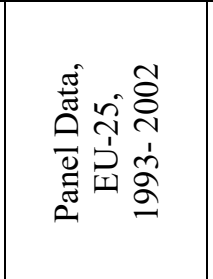 & 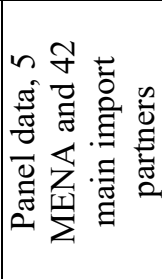 & 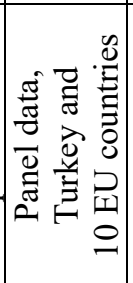 & 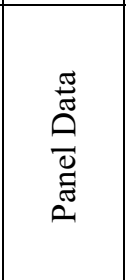 & 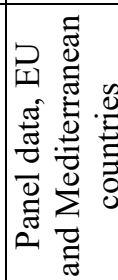 \\
\hline & 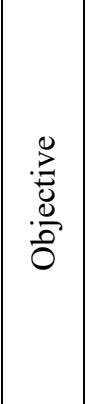 & 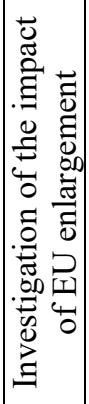 & 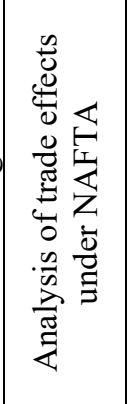 & 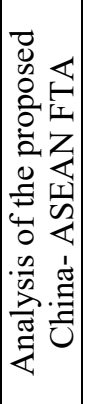 & 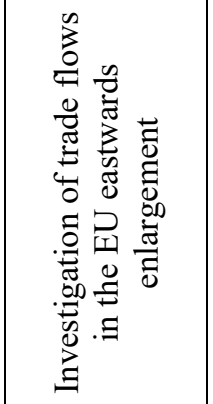 & 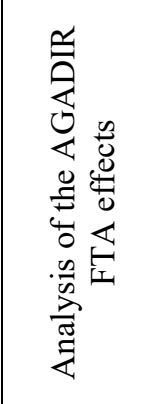 & 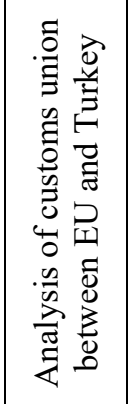 & 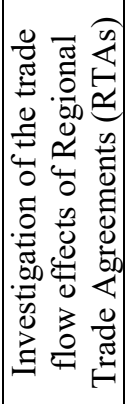 & 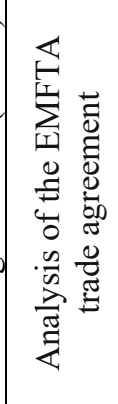 \\
\hline & 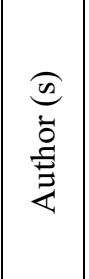 & 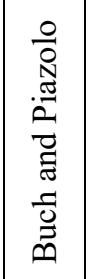 & 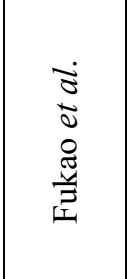 & 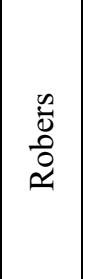 & 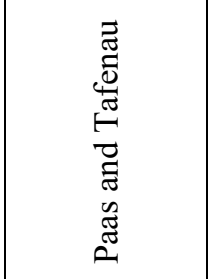 & 莺 & 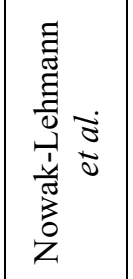 & 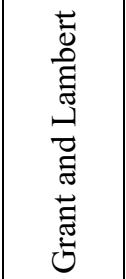 & 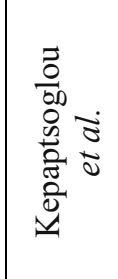 \\
\hline & $\stackrel{\check{\varpi}}{\check{\nu}}$ & ఠ్ & §ิి & ণ্ণ & ڤి & ڤి & 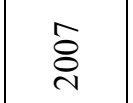 & $\stackrel{\infty}{\stackrel{\leftrightarrow}{\circ}}$ & 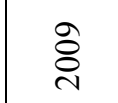 \\
\hline
\end{tabular}


In order to estimate the model parameters, a suitable group of reference countries must be used to gather the required data to then estimate Ukraine's expected trade under the AA/DCFTA. This assumes that Ukraine should export to the EU at levels similar to the exports of the reference group used to estimate the gravity equation. Therefore, this group should be similar in nature and particularly, the dummy must reflect the AA/DCFTA flag.

However, the AA/DCFTA is a new instrument of the EU and is a new kind of agreement. Therefore, although Ukraine is not on an accession path the legal approximation agenda and commitments of the AA/DCFTA are closer to "Accession terms" than any other trade agreement. For this model, the reference group used is newly acceding members of the EU from Eastern Europe. Western Balkans was considered as these too have an Association Agreement, but this seemed not appropriate as these countries are to some extent, less integrated currently in terms of legal approximation than Ukraine.

Results. As recommended by Baldwin et al. [23] the parameters were estimated using pooled panel data of Accession Countries' exports to the EU by log linear OLS regression.

\section{Equation 3: OLS Specification of Gravity Equation}

$$
\operatorname{In} X_{U k r, E U}=\text { Intercept }+\alpha \operatorname{In} G D P U k r+\beta \operatorname{In} G D P_{E U}+\gamma \ln D I S T_{U r k E U}+\delta \mathrm{D} .
$$

Initially, the resulting regression ordered the data by country and year and produced a model with adjusted $\mathrm{R}^{2}$ of $91 \%$ (goodness of fit of the equation to actual trade), but a Durbin Watson statistic of 0.34 which suggested autocorrelation of stochastic error (that is, the model is following its own trend rather than modelling the dependent variables). The OLS results are given in Appendix 1.

To overcome this autocorelation, the data was reordered randomly and re-estimated as shown in Appendix 2.

The resulting model had a high goodness of fit (R2) of $88 \%$, and no autocorrelation with a Durbin Watson (DW) of 2.22; with 4 dependent variables and 102 observations, the lower and upper limits range (inconclusive) for DW is $1.461-1.625$ and $2.375-2.539$.

The elasticity of the "dummy" policy variable for accession showed the expected impact of applying the policy to increase Ukraine's trade (through simulation) by $53 \%$ (difference with 2014 expected trade with and without the dummy). This is far higher than any of the literature predicted.

Considering the similarities of the policy of accession and AA/DCFTA, the assumption and use of acceding countries as a reference group is still valid, but further understanding of the complexities of the agreement and the implementation stages mean that the use of a single policy dummy to capture the effects was perhaps too ambitious.

The AA/DCFTA has two important parts: market access through the liberalisation in the EU of tariffs on Ukraine's imports and; alignment with EU business regulations (mostly technical regulations and sanitary and phytosanitary measures). This is also the mechanism during accession. Whilst in the case of the AA/DCFTA, the process of gaining market access and alig-

ISSN 1727-9313. HERALD OF KNUTE. 2019. 
ning legislation starts with the implementation of the agreement, the date of accession of acceding countries mark the end of the process and therefore, the accession dummy does not truly represent the AA/DCFTA. Therefore, two dummies in the model should be examined, the date of gaining virtually duty free market access and the beginning of the process of alignment of business legislation to the EU (that is, the date of formal accession launch when acceding countries start the legislative alignment process). Given that legislative alignment and market access to the EU did not always align, a separate dummy was used for each in the re-specified equation, $D_{1}$ and $D_{2}$ respectively. The combined dummy of $D_{1}$ and $D_{2}$ in the simulation of Ukraine's trade would show the expected impact of AA/DCFTA. The accession dummy $\left(D_{3}\right)$ was still included to show the expected impact once alignment under the DCFTA was completed (expected mostly on legislation in Title IV, Trade after 7 years of entry into force).

AA/DCFTA on Ukraine's trade using the following specification:

\section{Equation 4: Augmented Gravity Model for AA/DCFTA}

$$
X_{U k r, E U}=\frac{\left(G D P_{U k r}\right)^{\alpha} \cdot\left(G D P_{E U}\right)^{\beta} D_{1}^{\delta} \cdot D_{2}^{\zeta} \cdot D_{3}^{\eta}}{D I S T_{U k r E U}^{r}}
$$

$X_{U k r, E U}$ - Exports from Ukraine to the EU (measured by EU imports from Ukraine); $G D P_{U k r}$ - nominal GDP of Ukraine;

$G D P_{E U}$ - nominal GDP of EU;

Dist $_{U k r E U}$ - distance between Kiev and Berlin;

$D_{1}$ - Dummy of virtually free market access granted by EU;

$D_{2}$ - Dummy for the process of legislative alignment with EU business acquis based on commitments in international agreement;

$D_{3}$ - Dummy for Signature of Association Agreement.

For the regression estimates, the following data was used for recently acceded countries from Eastern Europe as shown in table 3.

Table 3

Scope of Data Used for Model Estimation

\begin{tabular}{|c|c|c|c|c|}
\hline Countrie & Data Set & $\begin{array}{c}\text { Date and basis } \\
\text { of EU Granting } \\
\text { free market Entry }\end{array}$ & $\begin{array}{c}\text { Date and basis } \\
\text { of launch of Accession } \\
\text { Negotiations }\end{array}$ & $\begin{array}{c}\text { Date of } \\
\text { Accession }\end{array}$ \\
\hline $\begin{array}{c}\text { Czech Republic, } \\
\text { Estonia, Hungary, } \\
\text { Poland, Slovenia }\end{array}$ & $1995-2008$ & $\begin{array}{c}\text { 1999 as declared by EU at EU Essen Summit } \\
\text { [25] setting out the pre Accession strategy }\end{array}$ & 2004 \\
\hline $\begin{array}{c}\text { Slovakia, } \\
\text { Lithuania, Latvia }\end{array}$ & $1997-2008$ & 1999 & \begin{tabular}{c} 
2000 official launch at \\
the Inter-governmental \\
Accession Conference \\
\cline { 1 - 2 } (Brussels) [26]
\end{tabular} & 2004 \\
\hline $\begin{array}{c}\text { Bulgaria and } \\
\text { Romania }\end{array}$ & $1997-2011$ & 1999 & 2007 & 2013 \\
\hline Croatia & $1995-2013$ & $\begin{array}{c}\text { 2000 under } \\
\text { the Autonomous } \\
\text { Trade Preferences } \\
\text { to Western } \\
\text { Balkans [27] }\end{array}$ & 2005 [28] & \\
\hline
\end{tabular}

Source: composed by the author according to [25-28]. 
The initial regression produced no significance for $D_{l}$, policy dummy for FTA market entry. This is because in all but a few country cases (Croatia, Bulgaria and Romania), the timing of application of market access to EU $\left(D_{l}\right)$ and start of accession negotiations and legislative alignment $\left(D_{2}\right)$ were the same. Therefore, the regression was re-run without $D_{1}$ and $D_{2}$ would be used as the AA/DCFTA proxy.

The regression results are presented in Appendix 3. The goodness of fit of the results is $89 \%$ (Adjusted $\mathrm{R}^{2}$ ) and the DW of 1.61 (which is within normal limits and all $\mathrm{t}$ statistics are significant within $5 \%$ confidence ( $>2.01$ with $5 \mathrm{df}$ ).

GDP of partner countries, and the two policy dummies are positive and significant as expected so that as GDP in the partner country (proxy for supply capacity) rises, so does trade and the application of agreement for market access and approximation and completion of the process also increases trade as market access and legislative alignment increases opportunity for trade. The distance coefficient (proxy for trade costs) is significant and negative as expected so that as trade costs increase, trade decreases.

Although EU GDP (proxy for demand) is significant, the sign is negative which is counter intuitive and not in line with all other models. That is, it is expected that as partner demand (EU grows), then exports from the country to the EU would also grow. However, it is possible for the partner country's GDP to have a negative effect on the value of trade [29]. For example, in an Heckscher-Ohlin model, if all the factors of production were to expand proportionately in the partner country, the partner's per capita GDP would remain unaffected while GDP rises. If the elasticity of foreign demand (here EU) for the country's exports is sufficiently low, then even though the quantity of exports may rise, their value may decline.

The resulting gravity model was thus specified:

\section{Equation 5: Augmented Gravity Model}

$$
\operatorname{In} X_{U k r, E U}=37.0+0.82 \operatorname{In} G D P_{U k r}-1.07 \operatorname{In} G D P_{E U}-0.32 \operatorname{InDIST} T_{U k r E U}+0.57 D_{2}+0.61 D_{3} .
$$

Based on recently eastern accessions to the EU, and using the above formulation, Ukraine's exports to the EU under the AA/DCFTA can be simulated using the $D_{2}$ dummy (accession process begins as proxy for AA/DCFTA implementation) and without $D_{2}$ to predict trade without implementing the AA/DCFTA. $D_{2}$ is then used to signal the signing of the AA/DCFTA (the point at which improved market access is offered and Ukraine starts the process of legislation alignment which is akin to the launch of accession negotiations for the reference countries used to specify the model).

$D_{3}$ in the EU accession gravity model is the completion of the accession process which will only happen (equivalent) once Ukraine has adopted the EU acquis (akin to membership) which is expected (and Ukraine committed) to be completed only 10 years after entry into force of the AA/DCFTA and so in the following simulation, $D_{3}$ is not used. 
Table 4 shows simulated and actual trade with the EU using the gravity model for acceding eastern European countries over the period immediately before application of the DCFTA and immediately after (four years):

Table 4

Ukraine's Trade with EU Simulated

\begin{tabular}{|c|c|c|c|}
\hline Year & $\begin{array}{c}\text { Modelled Exports } \\
\text { to EU,€ }\end{array}$ & $\begin{array}{c}\text { Actual Exports } \\
\text { to the EU, } €\end{array}$ & Differential, \% \\
\hline 2010 & 11.366 .479 .560 & 11.100 .825 .360 & -2.4 \\
\hline 2011 & 12.149 .520 .251 & 14.651 .406 .648 & 17.1 \\
\hline 2012 & 13.760 .811 .114 & 14.201 .384 .330 & 3.1 \\
\hline 2013 & 13.621 .804 .897 & 13.347 .435 .180 & -2.1 \\
\hline 2014 & 17.917 .526 .218 & 13.218 .532 .266 & -35.5 \\
\hline 2015 & 14.991 .753 .256 & 12.336 .451 .349 & -21.5 \\
\hline 2016 & 15.204 .472 .884 & 12.756 .762 .825 & -19.2 \\
\hline 2017 & 16.810 .272 .395 & 16.197 .138 .541 & -11.5 \\
\hline 2018 & 20.087 .797 .879 & 18.022 .713 .323 & \\
\hline
\end{tabular}

Source: composed by the author according to [30].

In the above simulation, the period prior to the AA/DCFTA (2010-2012) shows actual and forecast trade without AA/DCFTA and is a fairly good fit in most cases except for 2011. Therefore, it would be expected that the post AA/DCFTA model (2015-2018) should provide a good indicator of the expected benefit of the AA/DCFTA under frictionless trade (absence of other trade barriers).

Conclusion. In the period before the application of the DCFTA (2010-2013), the model shows that on average, actual exports are $3.9 \%$ higher than expected (simulated) exports to the EU from Ukraine, suggesting that the model is a relatively good match to explain Ukraine's trade with EU. However, following the implementation of the AA/DCFTA, the actual exports from Ukraine to EU is substantially lower (2015-2018) than simulated trade with $\mathrm{D}_{2}$ activated (that is with market access the launch of programme of alignment) at $14.8 \%$. Extending this to 2018 , actual performance in terms of Ukraine's exports to the EU under the AA/DCFTA is on average $14 \%$ lower than would have been expected. This confirms and correlates with the ex ante CGE models that Ukraine's exports to the EU under the DCFTA is much lower than expected.

Further research is therefore warranted to unpack Ukraine's export performance to the EU at a disaggregated level to identify specific elements that may explain this poor performance so that policy makers may address these and through better understanding, mitigate and enable business to take advantage of the export opportunity. Moreover, other countries entering free trade agreements can take a more realistic view of the expected impact of these agreements on exports. 
Appendix 1: Gravity Model Results (Panel data in Date order)

\begin{tabular}{|c|c|c|c|c|}
\hline \multicolumn{5}{|c|}{ Regression of variable XEU: } \\
\hline \multicolumn{5}{|c|}{ Goodness of fit statistics (XEU): } \\
\hline Observations & 102 & & & \\
\hline Sum of weights & 102 & & & \\
\hline DF & 97 & & & \\
\hline $\mathrm{R}^{2}$ & 0.88 & & & \\
\hline Adjusted $\mathrm{R}^{2}$ & 0.88 & & & \\
\hline MSE & 0.12 & & & \\
\hline RMSE & 0.34 & & & \\
\hline MAPE & 1.21 & & & \\
\hline DW & 0.47 & & & \\
\hline $\mathrm{Cp}$ & 5.00 & & & \\
\hline AIC & -213 & & & \\
\hline SBC & -200 & & & \\
\hline $\mathrm{PC}$ & 0 & & & \\
\hline \multicolumn{5}{|c|}{ Analysis of variance (XEU): } \\
\hline Source & DF & Sum of squares & Mean squares & $\mathrm{F}$ \\
\hline Model & 4 & 85 & 21 & 178 \\
\hline Error & 97 & 11 & 0 & \\
\hline Corrected Total & 101 & 96 & & \\
\hline \multicolumn{5}{|c|}{ Computed against model $\mathrm{Y}=\operatorname{Mean}(\mathrm{Y})$} \\
\hline \multicolumn{5}{|c|}{ Model parameters (XEU): } \\
\hline Source & Value & Standard error & $\mathrm{t}$ & $\operatorname{Pr}>|t|$ \\
\hline Intercept & 41.33 & 6.03 & 6.85 & $<0.0001$ \\
\hline GDP & 0.85 & 0.04 & 19.21 & $<0.0001$ \\
\hline GDPEU & -1.21 & 0.22 & -5.45 & $<0.0001$ \\
\hline Dist & -0.41 & 0.10 & -4.16 & $<0.0001$ \\
\hline Accession & 0.43 & 0.10 & 4.07 & $<0.0001$ \\
\hline
\end{tabular}

Source: composed by the author based on Eurostat data [30].

Appendix 2: Gravity Model Results (Panel data Randomised order)

\begin{tabular}{|lr}
\hline Goodness of fit statistics (XEU): \\
\hline Observations \\
Sum of weights & 102 \\
DF & 102 \\
R $^{2}$ & 97 \\
Adjusted R & 0.88 \\
MSE & 0.88 \\
RMSE & 0.12 \\
MAPE & 0.34 \\
DW & 1.21 \\
Cp & 2.22 \\
AIC & 5.00 \\
SBC & -213 \\
PC & -200 \\
\hline & 0 \\
\hline
\end{tabular}

Analysis of variance (XEU):

\begin{tabular}{|c|c|c|c|c|}
\hline Source & $\mathrm{DF}$ & Sum of squares & Mean squares & $\mathrm{F}$ \\
\hline Model & 4 & 85 & 21 & 178 \\
\hline Error & 97 & 11 & 0 & \\
\hline Corrected Total & 101 & 96 & & \\
\hline \multicolumn{5}{|c|}{ Computed against model $Y=\operatorname{Mean}(Y)$} \\
\hline \multicolumn{5}{|c|}{ Model parameters (XEU): } \\
\hline Source & Value & Standard error & $\mathrm{t}$ & $\operatorname{Pr}>|t|$ \\
\hline Intercept & 41.33 & 6.03 & 6.85 & $<0.0001$ \\
\hline GDP & 0.85 & 0.04 & 19.21 & $<0.0001$ \\
\hline GDPEU & -1.21 & 0.22 & -5.45 & $<0.0001$ \\
\hline Dist & -0.41 & 0.10 & -4.16 & $<0.0001$ \\
\hline Accession & 0.43 & 0.10 & 4.07 & $<0.0001$ \\
\hline
\end{tabular}

Source: composed by the author based on Eurostat data [30].

ISSN 1727-9313. HERALD OF KNUTE. 2019. 
Appendix 3: Augmented Gravity Model of Acceding Eastern European Members to EU

\begin{tabular}{|c|c|c|c|c|}
\hline \multicolumn{5}{|c|}{ Regression of variable XEU: } \\
\hline \multicolumn{5}{|c|}{ Goodness of fit statistics (XEU): } \\
\hline Observations & 155 & & & \\
\hline Sum of weights & 155 & & & \\
\hline DF & 149 & & & \\
\hline $\mathrm{R}^{2}$ & 0.90 & & & \\
\hline Adjusted $\mathrm{R}^{2}$ & 0.89 & & & \\
\hline MSE & 0.12 & & & \\
\hline RMSE & 0.35 & & & \\
\hline MAPE & 1.26 & & & \\
\hline DW & 1.61 & & & \\
\hline $\mathrm{Cp}$ & 6.00 & & & \\
\hline AIC & -320 & & & \\
\hline SBC & -302 & & & \\
\hline $\mathrm{PC}$ & 0 & & & \\
\hline \multicolumn{5}{|c|}{ Analysis of variance (XEU): } \\
\hline Source & $\overline{\mathrm{DF}}$ & Sum of squares & Mean squares & $\mathrm{F}$ \\
\hline Model & 5 & 156 & 31 & 255 \\
\hline Error & 149 & 18 & 0 & \\
\hline Corrected Total & 154 & 174 & & \\
\hline \multicolumn{5}{|c|}{ Computed against model $Y=\operatorname{Mean}(Y)$} \\
\hline \multicolumn{5}{|c|}{ Model parameters (XEU): } \\
\hline Source & Value & Standard error & $\mathrm{t}$ & $\operatorname{Pr}>|t|$ \\
\hline Intercept & 37.00 & 5.29 & 6.92 & $<0.0001$ \\
\hline GDP & 0.82 & 0.04 & 22.56 & $<0.0001$ \\
\hline GDPEU & -1.07 & 0.19 & -5.66 & $<0.0001$ \\
\hline Dist & -0.32 & 0.08 & -4.03 & $<0.0001$ \\
\hline $\mathrm{D} 2$ & 0.57 & 0.07 & 7.77 & $<0.0001$ \\
\hline $\mathrm{D} 3$ & 0.61 & 0.10 & 6.36 & $<0.0001$ \\
\hline
\end{tabular}

Source: composed by the author based on Eurostat data [30].

\section{REFERENCES}

1. Jakubiak, Magorzata \& Kolesnichenko, Anna \& Boyarchuk, Dmytro \& Golodniuk, Inna (2006). Prospects for EU-Ukraine Economic Relations. CASE - Center for Social and Economic Research [in English].

2. Usenko, Olga (2007). Review of the Impact of the Ukraine-EU Free Trade Agreement on Manufacturing Industries (Mechanical Engineering, Chemical and Light Industry). The Journal of International Economic Policy [in English].

3. Burakovsky, Igor \& Kutsenko, Kateryna \& Chukhai, Hanna \& Kobylyanska, Alla \& Movchan, Veronika \& Razdorozhny, Yevgen \& Sysenko, Natalia (2010). Costs and Benefits of FTA between Ukraine and the European Union. Institute For Economic Research and Policy Consulting, Ukraine [in English].

4. Petrov, Roman \& Van Der Loo, Guillaume \& Van Elsuwege, Peter (2015). The EU-Ukraine Association Agreement: A New Legal Instrument of Integration Without Membership? Kyiv-Mohyla Law and Politics Journal [in English].

5. Vošta, Milan \& Musiyenko, Svitlana \& Abrhám, Josef (2016). Ukraine-EU Deep and Comprehensive Free Trade Area as Part of Eastern Partnership initiative. Journal of International Studies[in English].

6. Hoekman, Bernard (2016). Deep and Comprehensive Free Trade Agreements. European University Institute, Italy [in English]. 
7. Adarov, Amat (20160. Trade Effects of DCFTA: Early Results, Challenges and Potential. Vienna Institute for International Economic Studies, Vienna, Austria [in English].

8. Berden, Koen \& Smakman, Floor \& Wymenga, Paul (2007). Trade Sustainability Impact Assessment for the FTA between the EU and Ukraine within the Enhanced Agreement. Ecorys Ltd Netherlands [in English].

9. Sidenko, Volodymyr (2007). EU-Ukraine Relations in the Context of a Possible Free Trade Agreement. EU Working Papers[in English].

10. Movchan, Veronika \& Giucci, Ricardo (2011). Quantitative Assessment of Ukraine's Regional Integration Options: DCFTA with European Union vs. Customs Union with Russia, Belarus and Kazakhstan. German Advisory Group Institute for Economic Research and Policy Consulting [in English].

11. Institute for Economic Research and Policy Consulting (2014). Consequences of the creation of in-depth and Comprehensive Free Trade Area between Ukraine and the EU, Institute for Economic Research and Policy Consulting [in English].

12. Kravchuk, Alexander \& Popovych, Zakhar. The expected impact of the EUUkraine Association Agreement. Transnational Institute, Amsterdam; Rosa Luxembourg Stiftung, Brussels; Center of Social and Labor Research, Kiev, 2016 [in English].

13. Ivus, Olena \& Aaron L. Strong (2007). Modeling Approaches to the Analysis of Trade Policy: Computable General Equilibrium and Gravity Models [in English].

14. Chaney, Thomas (2011). The Gravity Equation in International Trade: An Explanation. University of Chicago Press [in English].

15. Anderson, James E. (2011). The Gravity Model. Annual Review of Economics. (Vol. 3) [in English].

16. Disdier, Anne-Célia \& Keith Head (2008). The Puzzling Persistence of the Distance Effect on Bilateral Trade. Review of Economics and Statistics, 90(1): 37-48 [in English].

17. Levinsohn, James \& Leamer, Edward E. (1995). International Trade Theory: The Evidence, Handbook of International Economics [in English].

18. Tinbergen, Jan (1962). An Analysis of World Trade Flows. Shaping the World Economy. New York, NY: Twentieth Century Fund [in English].

19. Krugman, Paul (1980). Scale Economies, Product Differentiation, and the Patterns of Trade. American Economic Review, 70(5), 950-59 [in English].

20. Linnemann, H. (1966). An Econometric Study of International Trade Flows. Amsterdam [in English].

21. Yotov, Yoto V., Piermartini, Roberta, Monteiro, José-Antonio \& Larch, Mario (2016). Advantaged Guide to Trade Policy Analysis: Structural Gravity Models. United Nations and World Trade Organisation [in English].

22. Kepaptsoglou, Konstantinos, Karlaftis, Matthew G. \& Tsamboulas, Dimitrios (2010). The gravity model specification for modeling international trade flows and free trade agreement effects: a 10-year review of empirical studies. The Open Economics Journal [in English].

23. Tansey, Michael \& S. Hanson, Thomas (2011). The Gravity Model of Trade Applied to Developing Countries. Southern Business \& Economic Journal [in English].

24. Baldwin, Richard \& Taglioni, Daria (2006). Gravity for Dummies and Dummies for Gravity Equations. NBER Working Paper , 12516 [in English].

25. Retrieved from http://europa.eu/rapid/press-release_IP-94-1150_en.htm [in English].

26. Retrieved from https://www.touteleurope.eu/actualite/10th-anniversary-of-thestart-of-bulgaria-s-accession-negotiations-with-the-eu.html [in English]. 
27. Retrieved from http://europa.eu/rapid/press-release IP-10-173 en.htm?locale=en [in English].

28. Retrieved from https://ec.europa.eu/neighbourhood-enlargement/countries/detailedcountry-information/croatia en [in English].

29. WORLD BANK (2003). A gravity model of China's imports from the rest of East Asia. Asia Annual Review, World Bank [in English].

30. Retrieved from https://ec.europa.eu/eurostat/data/database [in English].

The article submitted to editor's office on 11.11.2019.

Хелласр М. Торгівля Украӥни в рамках ПВзВТ: гравітаційна модель.

Постановка проблеми. Підписання Угоди про асоиіацію між Україною та ЄС 21 березня 2014 р. передбачає створення поглибленої та всеохоплюючої зони вільної торгівлі (ПВЗВТ). У широкому сенсі ия угода має відкрити доступ Украӥні до ринку країн ЄС. Водночас, че передбачає, що Україна має схвалити низку законів, які будуть узгоджуватися з правилами ведення бізнесу в СС і сприятимуть експорту.

Аналіз останніх досліджень $і$ публікацій показав, що попри наявність окремих наукових доробок, залишається не вивченою детально проблема того, наскільки обтрунтованими були прогнози щодо зміни потенщіалу розвитку торгівлі Украӥни з СС за умови ПВЗВТ, зроблені на основі традииійної економічної теорії та моделей.

Метою статті є перевірка обтрунтованості та достовірності прогнозів щодо розвитку торгівлі Украӥни з СС за умови ПВЗВТ на основі гравітаційних моделей, а також надання рекомендаџій щодо їх врахування у межах підписання подібних угод.

Матеріали та методи. У дослідженні використано гравітаиіийі моделі, у т.ч. модель, що заснована на даних зведених панелей країн, асоиійованих або нещодавно приєднаних до СС. За основу взято припущення, що хоча Украӥна поки не стоїть на шляху остаточного приєднання до СС, для вивчення ї̈ ситуації найбільше підходить модель, де застосовується референтна група новоприєднаних членів СС зі Східної Європи.

Результати дослідження. На основі аналізу показників зовнішньої торгівлі України у межах поглибленої та всеохоплюючої зони вільної торгівлі презентовано практичні результати застосування положень ПВЗВТ в експорті України до ЄС. Проведено порівняння результатів торгівлі, що визначені із застосуванням гравітаційних моделей, та фактичні показники торгівлі. Результати иього порівняння свідчать, що прогнозні дані, які базувалися на традииійній економічній теорії та моделях і передбачали суттєве зростання експорту загалом, у реальній ситуації не справдилися у повному обсягу. Останне також стало свідченням того, щь у чих моделях не брались до уваги додаткові чинники, які могли завадити зростанню торгівлі. Запропоновано рекомендаиії для політиків, які беруть участь у перемовах щодо укладання подібних угод. Наголомено, що гравітаційне моделювання не завжди дає достатньо точні результати.

Висновки. У 2010-2013 рр. (до запровадження ПВЗВТ) гравітаційна модель показала, що в середньому фактичний експорт на $3.9 \%$ перевищував очікуваний (імітований) експорт до СС з України. Це дало змогу припустити, що модель порівняно добре підходить для опису торгівлі України з СС. Однак після впровадження ПВЗВТ (2015-2018 рр.) фактичний експорт з Украӥни до СС став нижчим, ніж було змодельовано: зокрема, у 2018 р. це відхилення становило $14 \%$ порівняно з очікуваним.

Подальші дослідження можуть бути присвячені деталізаиії аналізу експорту України до СС з метою визначення конкретних елементів, які б дали змогу пояснити низьку ефективність ПВЗВТ у випадку Украӥни. Це у свою чергу сформує передумови для покращання ситуації та дасть повноцінну можливість українському бізнесу скористатися експортними можливостями, що відкриває створення ПВЗВТ.

Ключові слова: лібералізація торгівлі, поглиблена та всеохоплююча зона вільної торгівлі, економічне зростання, тарифи, експорт, пільгові торговельні угоди, гравітаційна модель. 